\title{
Association between ERCC1 and XPA expression and polymorphisms and the response to cisplatin in testicular germ cell tumours
}

J Mendoza ${ }^{1}$, J Martínez ${ }^{2}, C_{\text {Hernández }}^{3}$, D Pérez-Montiel ${ }^{4}, \mathrm{C} \mathrm{Castro}^{1}$, E Fabián-Morales ${ }^{1}, \mathrm{M}$ Santibáñez ${ }^{1}$, R González-Barrios ${ }^{1}$, J Díaz-Chávez ${ }^{1}$, M A Andonegui ${ }^{1}, \mathrm{~N}$ Reynoso ${ }^{1}$, L F Oñate ${ }^{1}, \mathrm{M}$ A Jiménez ${ }^{5}, \mathrm{M} \mathrm{Núñez}^{6}$, R Dyer $^{7}$ and L A Herrera ${ }^{*}, 1$

${ }^{1}$ Unidad de Investigación Biomédica en Cáncer, Instituto Nacional de Cancerología (INCan)-Instituto de Investigaciones Biomédicas, Universidad Nacional Autónoma de México (UNAM), Avenida San Fernando 22, México D.F. 14080, México; ${ }^{2}$ Departamento de Oncología, INCan, Avenida San Fernando 22, México D.F., 14080, México; ${ }^{3}$ Servicio de Oncología Médica, Hospital Regional Presidente Juárez, Dr Gerardo Varela 617, Falda Cerro del Crestón, 68040 Oaxaca, México; ${ }^{4}$ Departamento de Patología, INCan, Avenida San Fernando 22, México D.F. 14080, México; ${ }^{5}$ Departamento de Urología, INCan, Avenida San Fernando 22, México D.F. 14080, México; ${ }^{6}$ Banco de Tumores, Instituto Nacional de Enfermedades Neoplásicas (INEN), Avenida Angamos Este 2520, Surquillo, Lima, Perú and ${ }^{7}$ Departamento de Patología, INEN, Avenida Angamos Este 2520, Surquillo, Lima, Perú

Background: Cisplatin cures over 80\% of testicular germ cell tumours (TGCTs), and nucleotide-excision repair (NER) modifies the sensitivity to cisplatin. We explored the association between NER proteins and their polymorphisms with cisplatin sensitivity (CPS) and overall survival (OS) of patients with non-seminomatous (ns)-TGCTs.

Methods: The expression of ERCC1 and XPA and the presence of $\gamma \mathrm{H} 2 \mathrm{AX}$ were evaluated in cancer cell lines and in fresh nsTGCTs. The ERCC1 protein was also determined in ns-TGCTs. The differences between CPS and non-CPS cell lines and patients were analysed by Student's $t$ - or $\chi^{2}$-tests. The differences in OS were analysed using the log-rank test, and the hazard ratios (HRs) were calculated using the Cox model.

Results: High ERCC1 expression was observed in the non-CPS cells, and both ERCC1 and $\gamma \mathrm{H} 2 \mathrm{AX}$ expressions were augmented after cisplatin treatment. Increased ERCC1 expression was also identified in non-CPS patients. Neither polymorphism was associated with either CPS or OS. The presence of ERCC1 was associated with non-CPS $(P=0.05)$ and adjusted in the prognosis groups. The HR in ERCC1-negative and non-CPS patients was $>14.43$, and in ERCC1-positive and non-CPS patients the HR was $>11.86(P<0.001)$.

Conclusions: High levels of ERCC1 were associated with non-CPS, suggesting that ERCC1 could be used as a potential indicator of the response to cisplatin and prognosis in ns-TGCTs.

Testicular cancer accounts for $1 \%$ of all cancers in men. It is the most frequent cancer in men under 40 years of age and has an incidence of 8.8/100000 and 5.3/100000 in Mexican and
Peruvian men, respectively (Globocan, 2008). Ninety per cent of testicular cancers are testicular germ cell tumours (TGCTs), which are classified as either seminomas or non-seminomas

*Correspondence: Dr LA Herrera; E-mail: herreram@biomedicas.unam.mx

Revised 15 May 2013; accepted 23 May 2013;

published online 27 June 2013

(C) 2013 Cancer Research UK. All rights reserved 0007-0920/13

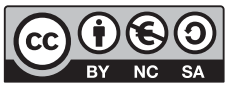

B) $\mathrm{C} \cap$ 
(Horwich et al, 2006). The cornerstone treatment of metastatic disease is cisplatin-based chemotherapy; over $80 \%$ of patients can be cured using this treatment (Schmoll et al, 2004). The bleomycinetoposide-cisplatin (BEP) regimen is considered to be the standard treatment (Williams et al, 1987). However, $20-30 \%$ of patients do not respond to BEP therapy. Thus, secondary courses of treatment are necessary and result in overall responses between $25-35 \%$ (Jones and Vasey, 2003).

Cisplatin acts as an antineoplastic agent mainly due to its capacity to induce DNA damage. The major DNA lesions induced by cisplatin are intrastrand DNA crosslinks, which induce DNA breaks that are recognised by $\gamma \mathrm{H} 2 \mathrm{AX}$ and can be potentially repaired. If the damage persists, the cell undergoes apoptosis (Siddik, 2003). Nucleotide-excision repair (NER) is the pathway that recognises intrastrand DNA crosslinks. In TGCTs, the mechanisms of tumour sensitivity to cisplatin have been associated with a decrease in the induction of repair (Köberle et al, 1997).

In the NER pathway, two proteins are associated with the sensitivity of TGCTs to cisplatin: the xeroderma pigmentosum group A (XPA) protein, which binds to the damaged DNA and recruits other NER proteins, and the excision repair crosscomplementation group 1 (ERCC1) protein, which, together with the XP group F (XPF) protein, excises the damaged DNA (Wood et al, 2005; Leibeling et al, 2006). The expression levels of XPA and ERCC1-XPF are low in TGCT-derived cell lines compared with other cancer cell lines, which may explain the higher sensitivity of TGCT-derived cell lines to cisplatin (Köberle et al, 1996; Köberle et al, 1997; Köberle et al, 1999; Welsh et al, 2004).

In patients with ovarian cancer, elevated levels of XPA and ERCC1 proteins are correlated with clinical resistance and poor survival (Stevens et al, 2005; Steffensen et al, 2008). A benefit of adjuvant cisplatin-based chemotherapy is associated with the absence of ERCC1 in patients with non-small cell lung cancer (Olaussen et al, 2007). In patients with cervical carcinoma, ERCC1 expression facilitates prediction of the response to cisplatin-based neoadjuvant chemotherapy followed by surgery (Park et al, 2011). ERCC1 expression contributes to the clinical outcome in patients treated with cisplatin-based induction chemotherapy for advanced head and neck squamous cell carcinoma (Handra-Luca et al, 2007).

There are several polymorphisms in the ERCC1 gene. Some of these polymorphisms result in silent mutations (Yu et al, 1997); however, some allelic variants, such as $8092 \mathrm{C}>\mathrm{A}$, have been associated with a decrease in the DNA repair capacity and with lower survival rates in patients with colon cancer and lung cancer (Park et al, 2003; Zhou et al, 2004). In addition, the XPA gene can contain a polymorphism in the $5^{\prime}$ non-coding region $(A \rightarrow G)$ that is located four nucleotides upstream of the ATG start codon (Saldivar et al, 2007). The functional effect of this polymorphism has not yet been elucidated.

In this work, we studied the association between the expression of ERCC1 and XPA, the polymorphisms in ERCC1 $(8092 \mathrm{C}>\mathrm{A})$ and the $5^{\prime}$ UTR of XPA, and the overall survival (OS) and sensitivity of non-seminomatous (ns)-TGCTs patients treated with cisplatin-based chemotherapy.

\section{MATERIALS AND METHODS}

Cancer cell lines. The human TGCT-derived NT2/D1 cell lines, bladder cancer-derived 1A6 and T-24 cell lines, and HeLa cell lines were used and maintained in DMEM supplemented with $10 \%(\mathrm{v} / \mathrm{v})$ fetal bovine serum and $1 \%$ antibiotics (penicillin/streptomycin) at $37^{\circ} \mathrm{C}$ in a $5 \% \mathrm{CO}_{2}$ atmosphere. The cells were incubated at the $\mathrm{IC}_{50}$ concentrations with cisplatin (Tecnoplatin, Columbia Lab., Mexico) for $1,15,18$ and $21 \mathrm{~h}$ at $37^{\circ} \mathrm{C}$ in a humidified atmosphere. All cell lines have been tested and authenticated.
$\mathrm{IC}_{50}$ concentrations were determined by plating 80000 cells in 24 chamber dishes containing $0.5 \mathrm{ml}$ medium, which were incubated overnight at $37^{\circ} \mathrm{C}$. After $1 \mathrm{~h}$ of exposure to a range of concentrations of cisplatin, the cells were washed with PBS and incubated in fresh medium for $24 \mathrm{~h}$. Cells were fixed with $70 \%$ ethanol at $-20{ }^{\circ} \mathrm{C}$, washed in PBS and stained with $1 \%$ crystal violet. After washing, the stain was solubilised in 33\% acetic acid, and the absorbance was determined in an ELISA reader at $570 \mathrm{~nm}$. The analyses were performed in triplicate in four independent experiments. The $\mathrm{IC}_{50}$ values were calculated by using linear regression analysis of the dose-response data using the points in the exponential region of the curve. The $\mathrm{IC}_{50}$ values used for the cisplatin experiments were $10 \mu \mathrm{m}$ for the HeLa and T-24 cell lines, $11 \mu \mathrm{m}$ for the $1 \mathrm{~A} 6$ cell line, and $4 \mu \mathrm{M}$ for the NT2/D1 cell line.

Patients. All cases were required to have an orchiectomy, to be confirmed as metastatic ns-TGCTs, to be classified by International Germ Cell Cancer Collaborating Group Classification (IGCCCGC) as having good, intermediate and poor prognosis, and to have combination chemotherapy with three to four BEP cycles (continuous infusion of 30 IU D2, D3, D4 of bleomycin; $100 \mathrm{mg} \mathrm{m}^{-2} \mathrm{D} 1-\mathrm{D} 5$ of etoposide; and $20 \mathrm{mg} \mathrm{m}^{-2} \mathrm{D} 1-\mathrm{D} 5$ of cisplatin per cycle). An oncologist determined the biochemical response of the tumours by the cycle of chemotherapy with specific tumour markers (TM): $\alpha$-fetoprotein, $\beta$-human chorionic gonadotrophin, and lactic dehydrogenase. After the third or fourth BEP cycle, the response was determined with TM and computed tomography of the thorax and abdomen according to the following criteria. The patients were classified as sensitive (CPS) if they presented a complete radiological response with no evidence of residual lesions or a biochemical response (negativisation of TM) to BEP, or if they showed negativisation of TM and complete surgical resection of the residual lesions and the histopathology showed necrosis, fibrosis, or mature teratoma. Patients were classified as non-CPS if they presented a persistence of TM after $\mathrm{BEP}$, unresectable residual disease, or if they showed radiological and biochemical disease progression. Patients treated with chemotherapy prior to orchiectomy, with extragonadal tumours, or without adequate biological material were excluded. This project was submitted to and approved by the local commissions of research and ethics in Mexico and Peru; an informed consent was obtained from patients.

Fresh tumour samples. One hundred and forty-two patients were diagnosed with TGCT at the National Cancer Institute of Mexico (INCan), and 35 of them met the inclusion criteria. In the Peruvian population, 82 patients were diagnosed with TGCT at the Instituto Nacional de Enfermedades Neoplásicas of Peru, and 24 of them met the inclusion criteria. Fresh tumour samples from patients were collected from January 2006 to December 2010 before the patients underwent BEP.

Paraffin-embedded tissue blocks. Paraffin-embedded testis specimen blocks were selected by a surgical pathologist, who confirmed that the blocks contained $>90 \%$ neoplastic tissue. These samples were obtained from 108 patients with metastatic ns-TGCTs that were treated with three to four BEP cycles from January 2000 to December 2006 at the INCan.

Real-time RT-PCR of ERCC1 and XPA in cancer cell lines. cDNA was synthesised from RNA samples and used as PCR templates with the following primers: ERCC1 $5^{\prime}$-CCT-GGG-AAT TTG-GCG-ACG-3' (forward) and 5'-GCG-GAG-GCT-GAG GAA-CAG-3' (reverse); XPA 5'-GCA-CCA-CTG-TAC-CCC AGG-3' (forward) and 5'-TAG-TTC-CCC-ACT-GTT-TCC-ACC $3^{\prime}$ (reverse). The PCR conditions were as follows: one cycle of $2 \mathrm{~min}$ at $94{ }^{\circ} \mathrm{C} ; 40$ cycles of $30 \mathrm{~s}$ at $94^{\circ} \mathrm{C}, 30 \mathrm{~s}$ at $65^{\circ} \mathrm{C}$, and $30 \mathrm{~s}$ at $72{ }^{\circ} \mathrm{C}$; and one cycle of $5 \mathrm{~min}$ at $72^{\circ} \mathrm{C}$. The data were analysed by the $2^{-\Delta \Delta \mathrm{CT}}$ method. 
Determination of $\gamma \mathrm{H} 2 \mathrm{AX}$ in cells treated with cisplatin. The presence of $\gamma \mathrm{H} 2 \mathrm{AX}$ was analysed to determine the percentage of double-strand breaks (DSBs) induced by cisplatin. Cells $\left(1 \times 10^{6}\right)$ were plated in $100-\mathrm{mm}$ dishes, incubated for $24 \mathrm{~h}$ at $37^{\circ} \mathrm{C}$, treated with the $\mathrm{IC}_{50}$ concentration of cisplatin for $1 \mathrm{~h}$ and then incubated in fresh medium for 15,18 , or $21 \mathrm{~h}$. The cells were rinsed, fixed, and incubated with anti- $\gamma \mathrm{H} 2 \mathrm{AX}$ (Ser139) antibody for $20 \mathrm{~min}$ (Millipore, 17-344, Billerica, MA, USA). The samples were then analysed with a BD FACSCanto II flow cytometer. The FACSDiva software version 6.1.3 (Becton-Dickinson Company, San Jose, CA, USA) was used for data analysis.

Real-time RT-PCR of ERCC1 and XPA in ns-TGCTs. The expression levels of ERCC1 and XPA were analysed in fresh nsTGCTs samples by real-time RT-PCR with the primers and conditions previously described. The analysis of these samples was performed by dividing them into two groups based on the patients' response to BEP chemotherapy (CPS or non-CPS).

Single-nucleotide polymorphism genotyping. For ns-TGCT patients, genomic DNA was extracted from paraffin-embedded neoplastic tissue; for healthy Mexican subjects, genomic DNA was extracted from peripheral blood samples. The genomic region containing the single-nucleotide polymorphism (SNP) ERCC1 $8092 \mathrm{C}>\mathrm{A}$ was amplified by PCR using the primers $5^{\prime}$-TAG-TTC CTC-AGT-TTC-CCG-3' (forward) and 5'-TGA-GCC-AAT-TCA GCC-ACT- $3^{\prime}$ (reverse), which generate a 255-bp fragment of the $3^{\prime}$ UTR of ERCC1. The PCR conditions were as follows: one cycle of $2 \mathrm{~min}$ at $94{ }^{\circ} \mathrm{C} ; 40 \mathrm{cycles}$ of $30 \mathrm{~s}$ at $94^{\circ} \mathrm{C}, 30 \mathrm{~s}$ at $52^{\circ} \mathrm{C}$, and $30 \mathrm{~s}$ at $72^{\circ} \mathrm{C}$; and one cycle of $5 \mathrm{~min}$ at $72^{\circ} \mathrm{C}$. The restriction enzyme MboII (New England BioLabs, Ipswich, MA, USA) was used to distinguish the genotypes in which the gain of an $M b o$ II restriction site occurs in the polymorphic allele. The wild-type allele has two MboII restriction sites that result in three bands (158, 91, and $6 \mathrm{bp}$ ), while the polymorphic allele possesses a single $M b o$ II restriction site in the $158 \mathrm{bp}$ fragment, which results in two bands (117 and $41 \mathrm{bp}$ ).

The genomic region containing the SNP $5^{\prime}$ UTR in XPA was amplified by PCR using the $5^{\prime}$-CTA-GGT-CCT-CGG-AGT-GGT CC-3' (forward) and 5'-GCC-CAA-ACC-TCC-AGT-AGC-C-3' (reverse) primer pair. The PCR conditions were as follows: one cycle of 2 min at $94^{\circ} \mathrm{C} ; 40$ cycles of $30 \mathrm{~s}$ at $94^{\circ} \mathrm{C}, 30 \mathrm{~s}$ at $62^{\circ} \mathrm{C}$, and $30 \mathrm{~s}$ at $72{ }^{\circ} \mathrm{C}$; and one cycle of $5 \mathrm{~min}$ at $72{ }^{\circ} \mathrm{C}$. The restriction enzyme BspEI (New England BioLabs) was used to distinguish the genotypes; the $A \rightarrow G$ single-nucleotide substitution in the $5^{\prime}$ flanking region created a $B s p E I$ restriction site. The wild-type genotype yielded a 204-bp fragment, the heterozygous genotype yielded 204-, 185-, and 19-bp fragments, and the polymorphic genotype yielded 185- and 19-bp fragments.

ERCC1 immunohistochemistry. Four-micrometre sections from paraffin-embedded tissue samples were incubated with a monoclonal antibody against the full-length human ERCC1 (clone 8F1, 1:300 dilution, code no. MS-671-P; Neomarkers, Lab Vision Corp., Fremont, CA, USA). Antibody binding was detected using diaminobenzidine as a substrate (DAKO, Glostrup, Denmark), and Harris hematoxylin was used as a counterstain (Merck, Darmstadt, Germany). Normal testis and normal tonsil tissue sections were included as external positive controls, while stromal cells surrounding the tumour area served as internal positive controls.

Microscopy analysis. Two pathologists evaluated ERCC1 staining by light microscopy at $\times 400$ magnification (Olympus U-D03, Tokyo, Japan); both were blinded to the clinical-pathological and biological characteristics of the patients. The staining intensities of both the tumour and the adjacent control tissue were graded on a scale from 0 to 3 , with a higher number indicating a higher intensity; the adjacent control tissue was used as a reference. Discordant cases were reviewed, and cases without internal controls were excluded. The percentage of positive tumour nuclei was calculated for each specimen, and a proportion score was assigned ( 0 if $0 \%, 0.1$ if $1-9 \%, 0.5$ if $10-49 \%$, and 1 if $50-100 \%$ ) as previously described (Al-Haddad et al, 1999; Handra-Luca et al, 2003). This proportion score was multiplied by the staining intensity of the nuclei to obtain a semiquantitative $\mathrm{H}$ score. The median value of all $\mathrm{H}$ scores was chosen as the cut-off point for separating ERCC1-positive tumours from ERCC1-negative tumours.

Statistical analysis. The differences among the CPS and non-CPS cell lines and patients were analysed by Student's $t$ - or $\chi^{2}$ tests. Replicates of each cell line were analysed by repeated measures ANOVA. The bivariate and multivariate associations of the independent variables and non-sensitivity were performed, employing the logistic regression model. The odds ratio (OR), along with its $95 \%$ confidence interval (CI), was quantified as a measure of each association. The Kaplan-Meier technique was used for survival analysis. The differences in OS between categories of interest were analysed using the log-rank test, and the hazard ratios (HRs) of the adjusted ERCC1 were calculated using the Cox model. All probability values of 0.05 or less were considered statistically significant, and two-tailed statistics were used in all cases. SPSS (version 18.0; SPSS, Inc., Chicago, IL, USA) was employed for data analysis.

\section{RESULTS}

Expression of ERCC1 and XPA in cancer cell lines. An increase in the basal ERCC1 expression level was observed in the non-CPS cancer cell lines (HeLa and T-24) compared with the NT2/D1 cell line $(P=0.013$ and 0.005 , respectively); XPA basal expression levels were not different in the four cancer cell lines (data not shown). As no differences were observed in the basal expression levels of XPA between the CPS and non-CPS cells, the time-course effect of cisplatin was only analysed for the expression of ERCC1. ERCC1 expression increased with time, and the increment was dependent on cisplatin treatment in the non-CPS cancer cell lines (Figure 1).

$\gamma \mathrm{H} 2 \mathrm{AX}$ presence in cells treated with cisplatin. The proportion of $\gamma \mathrm{H} 2 \mathrm{AX}$-positive cells increased in the non-CPS cancer cell lines after treatment with cisplatin $(1,15,18$, and $21 \mathrm{~h})$, and the percentage of positive cells increased steadily over time. In the NT2/D1 cell lines, an increase in the proportion of $\gamma \mathrm{H} 2 \mathrm{AX}$-positive cells was detected at 15 and $18 \mathrm{~h}$ but not at $21 \mathrm{~h}$ after cisplatin treatment (Figure 2).

Expression of ERCC1 and XPA in ns-TGCTs. To evaluate the role of ERCC1 and XPA in response to cisplatin-based chemotherapy (BEP), the patients were divided into CPS and non-CPS groups as previously described (Figure 3 ). In the Mexican population, $71.4 \%$ were CPS, and $75 \%$ were CPS in the Peruvian population. The results of Student's $t$-test analysis demonstrated an increase in the basal ERCC1 expression level in the non-CPS patients, both in the Mexican and in the Peruvian populations, compared with the CPS patients (Figure $3 \mathrm{~A}$ and $\mathrm{B}$ ). There was no difference in the $X P A$ expression levels between the CPS and non-CPS patients in either population (Figure $3 \mathrm{C}$ and D).

Characteristics of patients included in the SNP analysis and ERCC1 immunohistochemistry. The mean age of the included patients was 24.1 years (s.d. 5.2). A total of $38,30.5$, and $31.5 \%$ of patients were considered to have good, intermediate, or poor prognoses under the IGCCCGC, respectively. The most frequent sites for metastases included the lung (42.6\%), the retroperitoneum (87\%), and the mediastinum (9.3\%). Seventy-six patients $(70.4 \%)$ were CPS. 


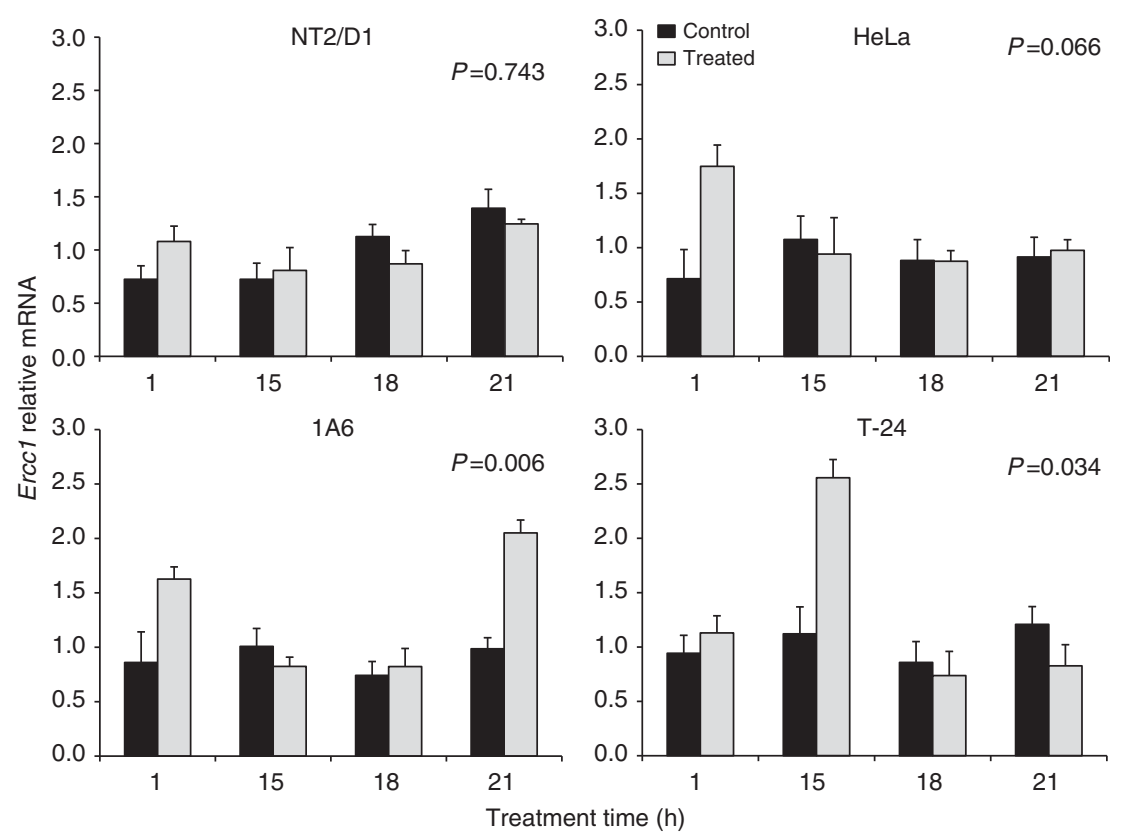

Figure 1. Temporal-course of ERCC1 expression in four cancer cell lines treated with cisplatin. P-values correspond to the effect of cisplatin treatment (repeated measures ANOVA); $P$-values associated with the effect of time were not shown.

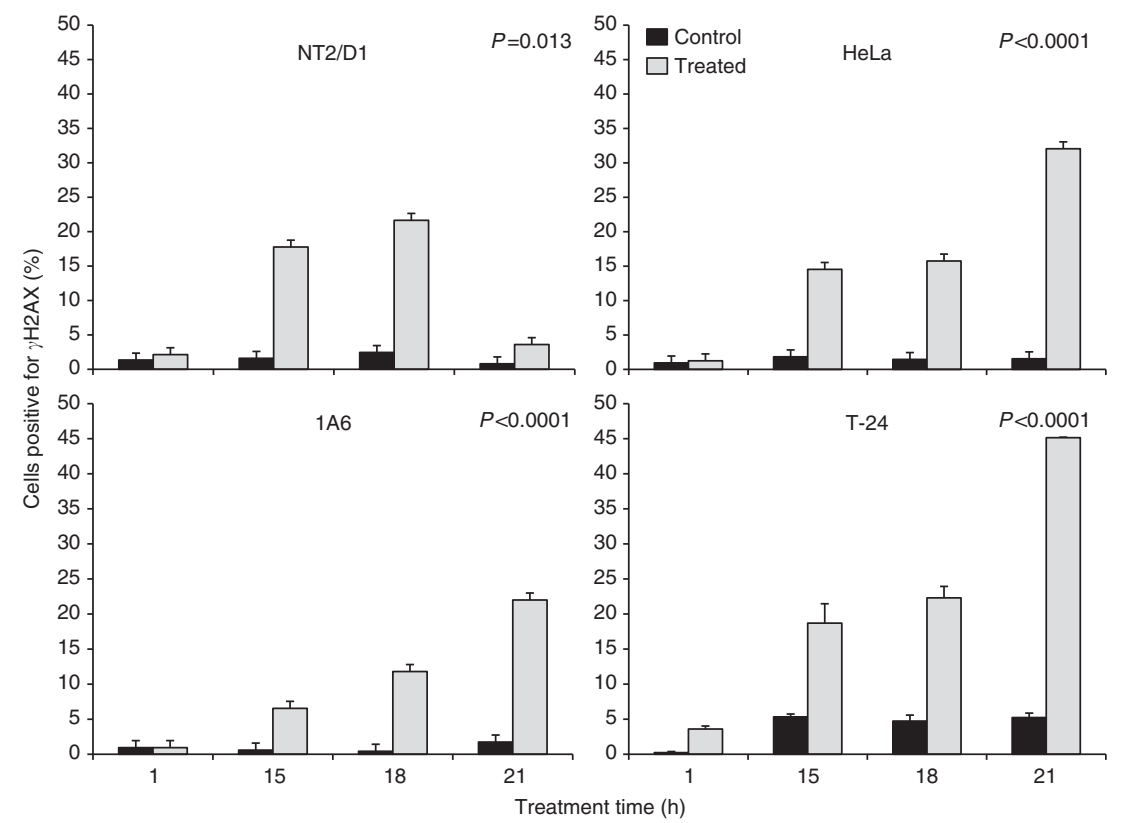

Figure 2. The proportion of $\gamma \mathrm{H} 2 \mathrm{AX}$-positive cells in four cancer cell lines treated with cisplatin. $P$-values correspond to the effect of cisplatin treatment (repeated measures ANOVA); $P$-values associated with the effect of time were not shown.

Seventy-three patients $(67.6 \%)$ were alive at the end of the study, and the median follow-up time of the cohort was 4.88 years (range, $0.28-11.4)$. Seven patients (6.5\%) presented with recurrent disease. The five-year OS probability of this cohort was $66 \%$, whereas the five-year OS probability for groups with good, intermediate, or poor prognosis was $94.7 \%, 54.7 \%$, and $43.9 \%$, respectively $(P<0.001)$. Patients considered CPS and non-CPS had a 5 -year OS probability of $91.9 \%$ and $9.4 \%$, respectively $(P<0.001)$.

The bivariate analysis revealed that ERCC1-positive patients had a 1.31-fold greater HR of death (CI 95\% 0.645-2.692) compared with ERCC1-negative patients $(P=0.448)$. Using a Cox model adjusted in the prognosis groups (IGCCCGC), the multivariate model (goodness of fit, $P<0.001$ by $\chi^{2}$-test) showed an interaction effect between the presence of ERCC1 and the response to cisplatin-based chemotherapy. Therefore, we decided to analyse the OS including the four groups of patients enclosed by these variables.

Immunohistochemical assessment of ERCC1. The median value of all $\mathrm{H}$ scores was 0 , and tumours with an $\mathrm{H}$ score exceeding 0 were considered ERCC1 positive. Figure 4 shows that ERCC1 was localised to the nucleus. ERCC1-positive immunostaining was observed in 30 out of 108 patients (27.8\%). There were no statistically significant differences in the presence of ERCC1 among histological subtypes. However, it is worth noting that of the 30 ERCC1-positive patients, 20 had a teratoma component (mixed teratoma), 7 were pure teratomas, and 3 did not have a teratoma component. Ten of the patients with a teratoma component were 

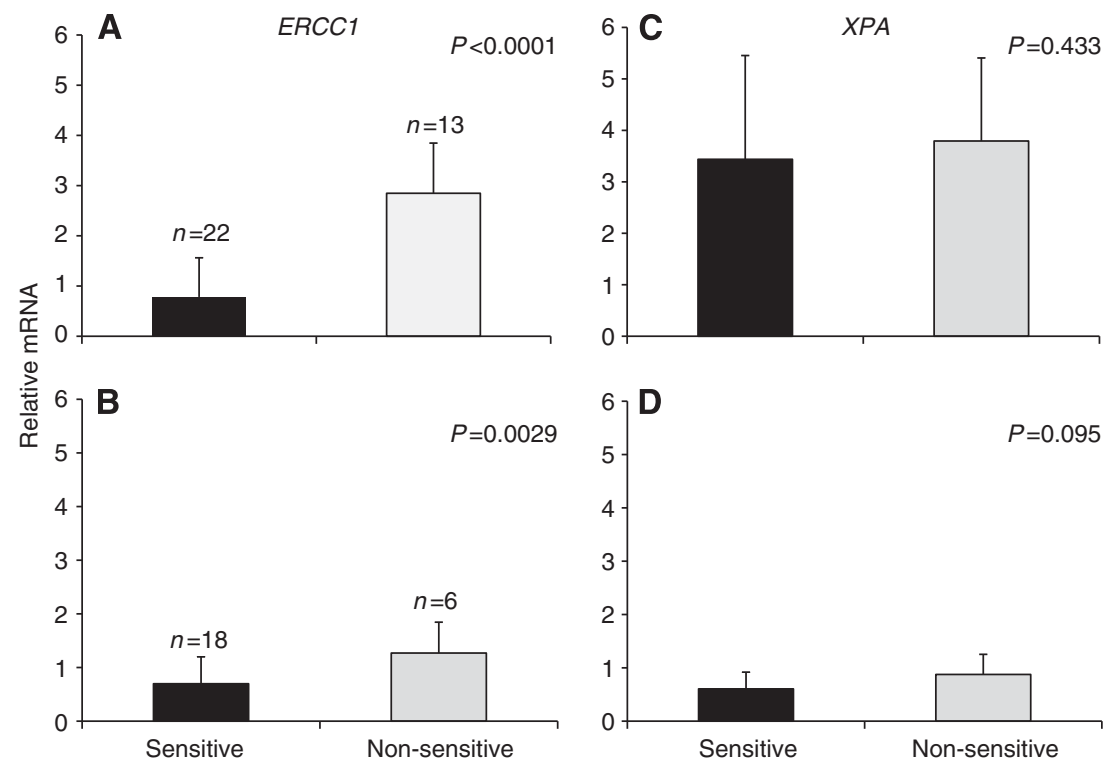

Figure 3. The expression of ERCC1 and XPA in Mexican and Peruvian patients with ns-TGCTs. (A) The relative quantification of ERCC1 mRNA in cisplatin sensitive and non-sensitive ns-TGCTs in the Mexican population. P-values were obtained with Student's t-test. (B) The relative quantification of ERCC1 mRNA in CPS and non-CPS ns-TGCTs in the Peruvian population. (C) The relative quantification of XPA mRNA in CPS and non-CPS ns-TGCTs in the Mexican population. (D) The relative quantification of XPA mRNA in CPS and non-CPS ns-TGCTs in the Peruvian population. P-values were obtained with Student's t-test.
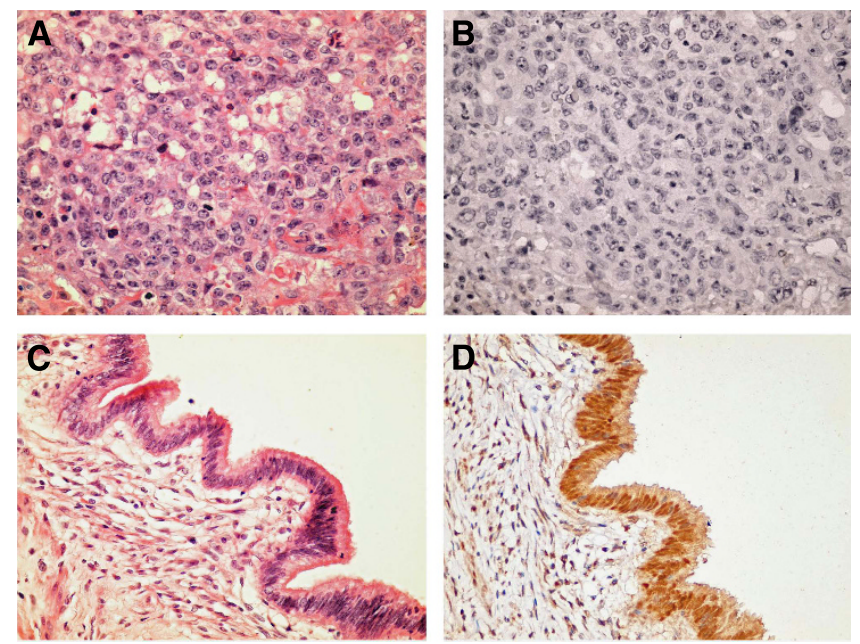

Figure 4. Representative examples of immunohistochemistry of ERCC1 in non-seminomatous testicular germ cell tumours.

(A) Hematoxylin and Eosin (H\&E) stained seminoma sample. (B) Negative tumour (seminoma) stained for ERCC1 protein. (C) H\&E-stained teratoma sample. (D) A tumour positive (teratoma) for ERCC1 protein (with a staining intensity of 3 ) and stromal cells negative for ERCC1 protein that served as an internal control. Nuclear signal (brown) is visualised with diaminobenzidine as the chromogen. $\times 400$ magnification.

non-CPS (33.3\%), four of them were pure teratomas (57.1\%), and six were mixed teratomas $(30 \% ; P=0.365$, Fisher's exact test).

ERCC1 staining and response to cisplatin-based chemotherapy. Of the 76 CPS patients, $59(77.6 \%)$ were ERCC1-negative and 17 (22.4\%) ERCC1-positive $(P=0.05)$. The clinical characteristics of patients with ns-TGCTs according to CPS and non-CPS are summarised in Table 1. ERCC1-positive nuclear staining was associated with non-CPS.
Table 1. Clinical characteristics of patients according to their response to cisplatin-based chemotherapy in ns-TGCTs

\begin{tabular}{|c|c|c|c|}
\hline & $\begin{array}{c}\text { Sensitive } \\
n=76 \\
n(\%)\end{array}$ & $\begin{array}{c}\text { Non-sensitive } \\
n=32 \\
n(\%)\end{array}$ & P-value \\
\hline Age & $23.96 \pm 4.58$ & $24.46 \pm 6.40$ & 0.64 \\
\hline \multicolumn{4}{|c|}{ IGCCCG classification } \\
\hline $\begin{array}{l}\text { Good prognosis } \\
\text { Intermediate } \\
\text { prognosis } \\
\text { Poor prognosis }\end{array}$ & $\begin{array}{l}40(52.63) \\
23(30.26) \\
13(17.11)\end{array}$ & $\begin{array}{c}1(3.13) \\
10(31.25) \\
21(65.63)\end{array}$ & $<0.001$ \\
\hline \multicolumn{4}{|c|}{ ERCC1 IHC presence } \\
\hline $\begin{array}{l}\text { Positive } \\
\text { Negative }\end{array}$ & $\begin{array}{l}17(22.37) \\
59(77.63)\end{array}$ & $\begin{array}{l}13(40.63) \\
19(59.38)\end{array}$ & 0.05 \\
\hline \multicolumn{4}{|c|}{ SNP ERCC1 $8092 \mathrm{C}>\mathrm{A}$} \\
\hline $\begin{array}{l}C / C \\
C / A \\
A / A\end{array}$ & $\begin{array}{l}30(40.54) \\
30(40.54) \\
14(18.92)\end{array}$ & $\begin{array}{r}12(38.71) \\
14(45.16) \\
5(16.13)\end{array}$ & 0.89 \\
\hline \multicolumn{4}{|c|}{ SNP XPA 5'UTR } \\
\hline $\begin{array}{l}\text { A/A } \\
A / G \\
G / G\end{array}$ & $\begin{array}{r}9(11.84) \\
43(56.58) \\
24(31.58)\end{array}$ & $\begin{array}{c}3(9.68) \\
18(58.06) \\
10(32.26)\end{array}$ & 0.94 \\
\hline \multicolumn{4}{|c|}{$\begin{array}{l}\text { Abbreviations: ERCC1 = excision repair cross-complementation group 1; IGCCCG } \\
\text { classification =International Germ Cell Cancer Collaborating Group classification; IHC= } \\
\text { immunohistochemistry; ns-TGCTs = non-seminomatous testicular germ cell tumours; } \\
\text { XPA=xeroderma pigmentosum group A. }\end{array}$} \\
\hline
\end{tabular}

Bivariate analysis showed that ERCC1-positive patients had a 2.37-fold greater OR of non-sensitivity to cisplatin-based chemotherapy compared with ERCC1-negative patients. In a multivariate model (goodness of fit, $P<0.001$ by $\chi^{2}$-test), the adjusted OR was $>2.95$ for patients with ERCC1-positive 95\% CI $(0.97-8.97 ; P=0.05)$. The results of the logistic regression model 
Table 2. Logistic regression model of ERCC1 and IGCCCG classification associated with the insensitivity to cisplatin-based chemotherapy in patients with ns-TGCTs

\begin{tabular}{|c|c|c|c|}
\hline & Odds ratio & $\begin{array}{c}95 \% \text { Confidence } \\
\text { interval }\end{array}$ & $P$-value \\
\hline \multicolumn{4}{|l|}{ Bivariate analysis } \\
\hline \multicolumn{4}{|l|}{ ERCC1 IHC presence } \\
\hline $\begin{array}{l}\text { Positive } \\
\text { Negative }\end{array}$ & $\begin{array}{l}2.37 \\
1\end{array}$ & $(0.97-5.77)$ & 0.05 \\
\hline \multicolumn{4}{|l|}{ IGCCCG classification } \\
\hline $\begin{array}{l}\text { Good prognosis } \\
\text { Intermediate prognosis } \\
\text { Poor prognosis }\end{array}$ & $\begin{array}{l}0.01 \\
0.26 \\
1\end{array}$ & $\begin{array}{c}(0-0.12) \\
(0.09-0.74)\end{array}$ & $\begin{array}{l}<0.001 \\
<0.001\end{array}$ \\
\hline \multicolumn{4}{|l|}{ Multivariate analysis } \\
\hline \multicolumn{4}{|l|}{ ERCC1 IHC presence } \\
\hline $\begin{array}{l}\text { Positive } \\
\text { Negative }\end{array}$ & $\begin{array}{l}2.95 \\
1\end{array}$ & $(0.97-8.97)$ & 0.05 \\
\hline \multicolumn{4}{|l|}{ IGCCCG classification } \\
\hline $\begin{array}{l}\text { Good prognosis } \\
\text { Intermediate prognosis } \\
\text { Poor prognosis }\end{array}$ & $\begin{array}{l}0.01 \\
0.241 \\
1\end{array}$ & $\begin{array}{c}(0-0.11) \\
(0.08-0.70)\end{array}$ & $\begin{array}{l}<0.001 \\
<0.001\end{array}$ \\
\hline \multicolumn{4}{|c|}{$\begin{array}{l}\text { Abbreviations: ERCC1 = excision repair cross-complementation group 1; IGCCCC } \\
\text { classification = International Germ Cell Cancer Collaborating Group classification; IHC= } \\
\text { immunohistochemistry; ns-TGCTs = non-seminomatous testicular germ cell tumours. }\end{array}$} \\
\hline
\end{tabular}

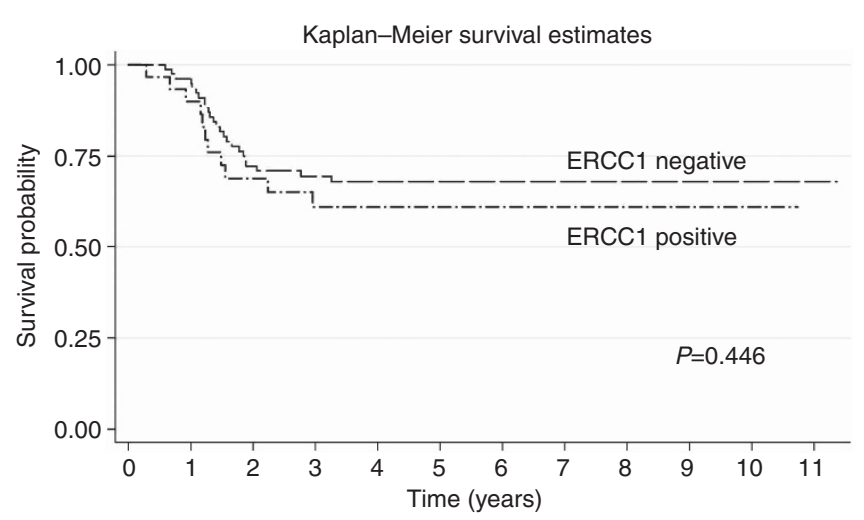

Figure 5. Kaplan-Meier curve. Five-year overall survival in patients with ns-TGCTs treated with cisplatin-based chemotherapy and the presence of ERCC 1 protein. The difference between the groups was $P=0.446$ (log-rank test)

of ns-TGCTs and insensitivity to cisplatin-based chemotherapy can be found in Table 2 .

ERCC1 staining and cancer-specific death. The OS was influenced by the response to cisplatin-based chemotherapy (CPS and non-CPS), and we found that this variable was strongly associated with the presence of ERCC1 by immunohistochemistry. OS analysis was performed in four groups of patients: (a) ERCC1positive and non-CPS (13/108); (b) ERCC1-positive and CPS (17/108); (c) ERCC1-negative and CPS (59/108); and (d) ERCC1negative and non-CPS (19/108). The median survival time was lower in the non-CPS patients who were either ERCC1-positive (1.27 years) or ERCC1-negative (1.30 years) compared with the
Table 3. Hazard ratios for cancer death in the Cox model adjusted in the prognosis groups in ns-TGCTs treated with cisplatin-based

chemotherapy

\begin{tabular}{|l|l|c|l|}
\hline & Hazard ratio & $\begin{array}{c}\text { 95\% Confidence } \\
\text { interval }\end{array}$ & $P$-value \\
\hline
\end{tabular}

Bivariate analysis

\section{ERCC1 IHC and CPS/non-CPS}

\begin{tabular}{|c|c|c|c|}
\hline $\begin{array}{l}\text { Positive and non-CPS } \\
\text { Negative and non-CPS } \\
\text { Negative and CPS }\end{array}$ & $\begin{array}{c}17.06 \\
20.75 \\
1\end{array}$ & $\begin{array}{l}(6.24-46-62) \\
(8.06-53.42)\end{array}$ & $\begin{array}{l}<0.001 \\
<0.001\end{array}$ \\
\hline \multicolumn{4}{|l|}{ IGCCCG classification } \\
\hline $\begin{array}{l}\text { Good prognosis } \\
\text { Intermediate prognosis } \\
\text { Poor prognosis }\end{array}$ & $\begin{array}{l}0.06 \\
0.63 \\
1\end{array}$ & $\begin{array}{l}(0.01-0.26) \\
(0.31-1.26)\end{array}$ & $\begin{array}{c}<0.001 \\
0.19\end{array}$ \\
\hline
\end{tabular}

Multivariate analysis

ERCC1 IHC and CPS/non-CPS ${ }^{a}$

\begin{tabular}{|l|c|c|c|}
\hline Positive and non-CPS & 11.86 & $(3.88-36.21)$ & $<0.001$ \\
Negative and non-CPS & 14.43 & $(4.98-41.81)$ & $<0.001$ \\
Negative and CPS & 1 & & \\
\hline
\end{tabular}

\section{IGCCCG classification}

\begin{tabular}{|l|l|l|l|}
\hline Good prognosis & 0.38 & $(0.07-2.05)$ & 0.26 \\
Intermediate prognosis & 0.92 & $(0.45-1.91)$ & 0.84 \\
Poor prognosis & 1 & & \\
\hline
\end{tabular}

Abbreviations: $\mathrm{CPS}=$ cisplatin sensitive; $\mathrm{ERCC1}$ = excision repair cross-complementation group 1; IGCCCG classification=International Germ Cell Cancer Collaborating Group classification; $\quad I H C=$ immunohistochemistry; non-CPS=non-cisplatin sensitive; ns-TGCTs $=$ non-seminomatous testicular germ cell tumours.

a The hazard ratio and confident interval values could not be estimated for the ERCC1-positive and CPS patients group because the deaths were not presented.

CPS patients, who had a median survival time of 6.31 years, independent of their ERCC1 status. The Kaplan-Meier curve showed a lower 5-year OS probability for the ERCC1-negative and non-CPS patients (5.26\%) compared with the ERCC1-positive and non-CPS patients (15.38\%). The OS probability for the ERCC1positive and CPS patients was greater (100\%) than for the ERCC1negative and CPS patients (89.3\%) (Figure 5). The 5-year OS probability of the ERCC1-negative and CPS patients was greater than that of the ERCC1-positive and non-CPS patients $(P<0.001)$.

Bivariate analysis indicated that the ERCC1-positive and nonCPS patients had an HR of 17.06, and the ERCC1-negative and non-CPS patients had an HR of death of 20.75 HR compared with the ERCC1-negative and CPS patients $(P<0.001)$. Using a Cox model adjusted in the prognosis groups (IGCCCGC), the HR of death in the ERCC1-negative and non-CPS patients was $>14.43$ in the multivariate model (goodness of fit, $P<0.001$ by $\chi^{2}$-test), and in the ERCC1-positive and non-CPS patients, the HR was $>11.86(P<0.001)$. The adjusted ratios of the prognosis groups were not predictive in this model. The results of the Cox model of IGCCCG classification, the presence of ERCC1 and the response to cisplatin-based chemotherapy in ns-TGCTs are shown in Table 3. We did not observe an impact of the presence of ERCC1 on the OS of patients, most likely because the OS of ns-TGCT patients is affected by multiple factors that were not measured in this study and not just by the response to treatment with the first line of BEP.

ERCC1 8092C $>$ A and $5^{\prime}$ UTR XPA SNP genotyping. For the ERCC1 $8092 \mathrm{C}>\mathrm{A}$ SNP analysis, 42 patients were C/C (40\%), 44 were $\mathrm{C} / \mathrm{A}(42 \%)$, and 19 were A/A (18\%). For the $5^{\prime}$ UTR XPA 
SNP analysis, 12 patients were A/A (11\%), 61 were A/G (57\%) and 34 were $\mathrm{G} / \mathrm{G}(32 \%)$. These polymorphisms were not associated with the cisplatin response (Table 1), the OS, or any other clinical-pathological variables studied (data not shown). These polymorphisms were in Hardy-Weinberg equilibrium: the calculated $\chi^{2}\left(3.55\right.$ and 3.05 for ERCC1 $8092 \mathrm{C}>\mathrm{A}$ and $5^{\prime}$ UTR XPA, respectively) $<$ value of $\chi^{2}(3.84)$, considering one degree of freedom and $P=0.05$.

The frequencies of the polymorphic alleles were 0.48 for ERCC1 $8092 \mathrm{C}>\mathrm{A}$ and 0.60 for the XPA $5^{\prime}$ UTR in patients with nsTGCTs; these frequencies were the same as the frequencies observed in a sample of 124 and 161 healthy Mexicans. For the ERCC1 $8092 \mathrm{C}>\mathrm{A}$ SNP analysis, 33 (26.6\%) individuals were $\mathrm{C} / \mathrm{C}, 64(51.6 \%)$ were $\mathrm{C} / \mathrm{A}$, and $27(21.8 \%)$ were $\mathrm{A} / \mathrm{A}$; for the $5^{\prime}$ UTR XPA SNP, 27 (16.8\%) individuals were A/A, 76 (47.2\%) were $\mathrm{A} / \mathrm{G}$ and $58(36 \%)$ were $\mathrm{G} / \mathrm{G}$. In the healthy Mexican population, these polymorphisms were in Hardy-Weinberg equilibrium; the calculated $\chi^{2}\left(0.19\right.$ and 3.74 for ERCC1 $8092 \mathrm{C}>\mathrm{A}$ and $5^{\prime}$ UTR $X P A$, respectively) $<$ value of $\chi^{2}$ (3.84), considering one degree of freedom and $P=0.05$. Associations between the polymorphisms and the ERCC1 and XPA expression levels were not identified.

\section{DISCUSSION}

The in vitro sensitivity of neoplastic cells to cisplatin has been reported to be inversely proportional to the NER capacity of the cells. Therefore, the overexpression of ERCC1 and XPA has been correlated with non-CPS. TGCTs are hypersensitive to cisplatinbased chemotherapy and possess a reduced capacity for removing cisplatin adducts in DNA (Köberle et al, 1996, 1997, 1999). In this study, we evaluated the association of the DNA repair proteins ERCC1 and XPA and the $8092 C>A$ and $5^{\prime}$ UTR polymorphisms in ERCC1 and XPA, respectively, with the CPS and OS of patients with ns-TGCTs.

Our data confirmed the association between ERCC1 expression and CPS in cancer cell lines. An increase in ERCC1 expression in the non-CPS cancer cell lines was observed compared with the NT2/D1 cell lines. XPA expression was not associated with CPS. In the NT2/D1 cell lines, a decrease in the proportion of $\gamma \mathrm{H} 2 \mathrm{AX}$ positive cells was observed after cisplatin treatment, suggesting an accumulation of adducts in these cells that induces DSB formation and activates cell death. This result suggests that the TGCT-derived cells are unable to increase the expression of ERCC1, and as a result DNA repair is deficient in these cells. A recent study has reported an accumulation of $\gamma \mathrm{H} 2 \mathrm{AX}$ fluorescence in testicular cancer cell lines after exposure to cisplatin for 3,24, and $48 \mathrm{~h}$ (Fenske et al, 2012). Our results obtained in the time-course experiments confirmed these observations.

The observed association between ERCC1, but not XPA, and cisplatin treatment in the NT2/D1 cell lines is supported by previous studies in TGCT-derived cell lines (Honecker, 2003; Köberle et al, 2008). Non-seminomatous TGCTs patients were characterised as having increased ERCC1 expression compared with seminomas and normal testicular tissue (Köberle et al, 2010). These results support a prior study that identified decreased crosslink repair induced by cisplatin in testicular tumour cells because of diminished ERCC1-XPF expression (Usanova et al, 2010). An increase in ERCC1 expression has been reported in testicular cancer cell lines with acquired resistance compared with the parental cell line (Taverna et al, 1994). In our study, we observed an increase in the expression of ERCC1 after treatment with cisplatin only in cell lines with primary resistance, but not in the sensitive testicular cancer cell line.

The ERCC1 expression levels in samples of BEP chemo-naive ns-TGCTs obtained from Mexican and Peruvian populations support the important role of ERCC1 in the sensitivity of TGCTs to cisplatin therapy. Our results suggest a role for ERCC1 expression that is associated with the response to cisplatin-based chemotherapy in independent cohorts with ns-TGCTs.

Immunohistochemistry showed that the ERCC1-positive patients were correlated with non-CPS. These observations suggest that ERCC1 is involved in the sensitivity to cisplatin in ns-TGCTs. The absence of the ERCC1 protein in ns-TGCTs is associated with deficient DNA repair of cisplatin-induced DNA damage and, as a result, with a better response to cisplatin-based chemotherapy. However, we did not find any differences in the presence of ERCC1 among the diverse histological subtypes of ns-TGCTs or an association of these subtypes with the response to cisplatin-based chemotherapy. A similar result was reported in a previous study that investigated the association between the presence of various proteins involved in the cell cycle, apoptosis, and drug detoxification in different histological subtypes of TGCT and the response to chemotherapy, concluding that none of the evaluated parameters could explain the resistant phenotype of TGCT (Mayer et al, 2003).

To our knowledge, this is the first study to identify these polymorphisms in ns-TGCTs. In patients with lung cancer who were treated with cisplatin, it was demonstrated that the $8092 \mathrm{C}>\mathrm{A}$ polymorphism of ERCC1 is associated with decreased OS (Zhou et al, 2004). The polymorphism in the $5^{\prime}$ UTR of XPA is associated with both decreased OS and decreased disease-free survival in women with ovarian cancer who were treated with cisplatin-based chemotherapy (Saldivar et al, 2007). In contrast, we did not identify an association between these SNPs and either CPS or OS.

The results suggest a role for DNA repair proteins, specifically ERCC1, in both CPS and OS in ns-TGCTs. The response to cisplatin-based chemotherapy and the presence of the ERCC1 were two prognosis factors in determining the probability of survival in ns-TGCTs. The strong interaction of these factors observed in a multivariate analysis demonstrates the importance of determining the presence of ERCC1 in non-CPS patients. In addition, it remains unknown why ERCC1-negative and non-CPS patients are not cured with cisplatin-based chemotherapy; these patients must possess unknown factors that make them non-sensitive.

These findings should be confirmed in a prospective trial to determine whether cisplatin should be used as part of the chemotherapeutical scheme for ns-TGCTs with advanced disease based on the ERCC1 status. Moreover, it is extremely important to identify patients who are potentially non-sensitive to cisplatinbased chemotherapy to diminish the toxicity of cisplatin and improve their quality of life by avoiding the adverse effects caused by this agent. To date, a chemotherapy regimen demonstrating superiority to the standard chemotherapy (BEP) does not exist. However, once these non-CPS patients are identified, a diseasemanagement protocol without cisplatin could be employed for nsTGCTs with advanced disease.

\section{ACKNOWLEDGEMENTS}

This work was supported by the Consejo Nacional de Ciencia y Tecnología (CONACyT, grant number 83959) and the Programa de Apoyo a Proyectos de Investigación e Innovación Tecnológica of the Universidad Nacional Autónoma de México (PAPIIT, grant number IN213311); JM was a fellow of the Programa de Doctorado en Ciencias Biomédicas, UNAM, Mexico City, Mexico.

\section{CONFLICT OF INTEREST}

The authors declare no conflict of interest. 


\section{REFERENCES}

Al-Haddad S, Zhang Z, Leygue E, Snell L, Huang A, Niu Y, Hiller-Hitchcock T, Hole K, Murphy LC, Watson PH (1999) Psoriasin (S100A7) expression and invasive breast cancer. Am J Pathol 155(6): 2057-2066.

Fenske AE, Glaesener S, Bokemeyer C, Thomale J, Dahm-Daphi J, Honecker F, Dartsch DC (2012) Cisplatin resistance induced in germ cell tumour cells is due to reduced susceptibility towards cell death but not to altered DNA damage induction or repair. Cancer Lett 324(2): 171-178.

Globocan (2008) Testis cancer incidence and mortality worldwide in 2008 http://globocan.iarc.fr.

Handra-Luca A, Bilal H, Bertrand JC, Fouret P (2003) Extra-cellular signalregulated ERK-1/ERK-2 pathway activation in human salivary gland mucoepidermoid carcinoma: association to aggressive tumor behavior and tumor cell proliferation. Am J Pathol 163(3): 957-967.

Handra-Luca A, Hernandez J, Mountzios G, Taranchon E, Lacau-St-Guily J, Soria JC, Fouret P (2007) Excision repair cross complementation group 1 immunohistochemical expression predicts objective response and cancer-specific survival in patients treated by cisplatin-based induction chemotherapy for locally advanced head and neck squamous cell carcinoma. Clin Cancer Res 13(13): 3855-3859.

Honecker F (2003) Xeroderma pigmentosum group a protein and chemotherapy resistance in human germ cell tumors. Lab Invest 83: 1489-1495.

Horwich A, Shipley J, Huddart R (2006) Testicular germ-cell cancer. Lancet 367: 754-765.

Jones RH, Vasey PA (2003) Part II: testicular cancer-management of advanced disease. Lancet Oncol 4(12) 738-747.

Köberle B, Brenner W, Albers A, Usanova S, Thuroff JW, Kaina B (2010) ERCC1 and XPF expression in human testicular germ cell tumors. Oncol Rep 23(1): 223-227.

Köberle B, Grimaldi KA, Sunters A, Hartley JA, Kelland LR, Masters JR (1997) DNA repair capacity and cisplatin sensitivity of human testis tumour cells. Int J Cancer 70(5): 551-555.

Köberle B, Masters JR, Ja Hartley, Wood RD (1999) Defective repair of cisplatin-induced DNA damage caused by reduced XPA protein in testicular germ cell tumours. Curr Biol 9: 273-276.

Köberle B, Payne J, Ka Grimaldi, Ja Hartley, Masters JR (1996) DNA repair in cisplatin-sensitive and resistant human cell lines measured in specific genes by quantitative polymerase chain reaction. Biochem Pharmacol 52: 1729-1734.

Köberle B, Roginskaya V, Zima KS, Masters JRW, Wood RD (2008) Elevation of XPA protein level in testis tumor cells without increasing resistance to cisplatin or UV radiation. Mol Carcinog 47: 580-586.

Leibeling D, Laspe P, Emmert S (2006) Nucleotide excision repair and cancer. J Mol Histol 37(5-7): 225-238.

Mayer F, Stoop H, Scheffer GL, Scheper R, Oosterhuis JW, Looijenga LHJ, Bokemeyer C (2003) Molecular determinants of treatment response in human germ cell tumors. Clin Cancer Res 9: 767-773.

Olaussen Ka, Fouret P, Kroemer G (2007) ERCC1-specific immunostaining in non-small-cell lung cancer. N Engl J Med 357: 1559-1561.

Park DJ, Zhang W, Stoehlmacher J, Tsao-Wei D, Groshen S, Gil J, Yun J, Sones E, Mallik N, Lenz HJ (2003) ERCC1 gene polymorphism as a predictor for clinical outcome in advanced colorectal cancer patients treated with platinum-based chemotherapy. Clin Adv Hematol Oncol 1(3): $162-166$.

Park J-S, Jeon EK, Chun SH, Won HS, Lee A, Hur SY, Lee KH, Bae S-N, Yoon S-C, Hong SH (2011) ERCC1 (excision repair cross-complementation group 1) expression as a predictor for response of neoadjuvant chemotherapy for FIGO stage 2B uterine cervix cancer. Gynecol Oncol 120: $275-279$.

Saldivar JS, Lu KH, Liang D, Gu J, Huang M, Vlastos A-T, Follen M, Wu X (2007) Moving toward individualized therapy based on NER polymorphisms that predict platinum sensitivity in ovarian cancer patients. Gynecol Oncol 107: S223-S229.

Schmoll HJ, Souchon R, Krege S, Albers P, Beyer J, Kollmannsberger C, Fossa SD, Skakkebaek NE, de Wit R, Fizazi K, Droz JP, Pizzocaro G, Daugaard G, de Mulder PH, Horwich A, Oliver T, Huddart R, Rosti G, Paz Ares L, Pont O, Hartmann JT, Aass N, Algaba F, Bamberg M, Bodrogi I, Bokemeyer C, Classen J, Clemm S, Culine S, de Wit M, Derigs HG, Dieckmann KP, Flasshove M, Garcia del Muro X, Gerl A, Germa-Lluch JR, Hartmann M, Heidenreich A, Hoeltl W, Joffe J, Jones W, Kaiser G, Klepp O, Kliesch S, Kisbenedek L, Koehrmann KU, Kuczyk M, Laguna MP, Leiva O, Mead GM, Mueller RP, Nicolai N, Oosterhof GO, Pottek T, Rick O, Schmidberger H, Sedlmayer F, Siegert W, Studer U, Tjulandin S, von der Maase H, Walz P, Weinknecht S, Weissbach L, Winter E, Wittekind C (2004) European consensus on diagnosis and treatment of germ cell cancer: a report of the European Germ Cell Cancer Consensus Group (EGCCCG). Ann Oncol 15(9): 1377-1399.

Siddik ZH (2003) Cisplatin: mode of cytotoxic action and molecular basis of resistance. Oncogene 22: 7265-7279.

Steffensen KD, Waldstrom M, Jeppesen U, Brandslund I, Jakobsen A (2008) Prediction of response to chemotherapy by ERCC1 immunohistochemistry and ERCC1 polymorphism in ovarian cancer. Int J Gynecol Cancer 18(4): 702-710.

Stevens EV, Raffeld M, Espina V, Kristensen GB, Trope' CG, Kohn EC, Davidson B (2005) Expression of xeroderma pigmentosum A protein predicts improved outcome in metastatic ovarian carcinoma. Cancer 103: 2313-2319.

Taverna P, Hansson J, Scanlon KJ, Hill BT (1994) Gene expression in $\mathrm{X}$-irradiated human tumour cell lines expressing cisplatin resistance and altered DNA repair capacity. Carcinogenesis 15(9): 2053-2056.

Usanova S, Piée-Staffa A, Sied U, Thomale J, Schneider A, Kaina B, Köberle B (2010) Cisplatin sensitivity of testis tumour cells is due to deficiency in interstrand-crosslink repair and low ERCC1-XPF expression. Mol Cancer 9: 248.

Welsh C, Day R, McGurk C, Masters JRW, Wood RD, Köberle B (2004) Reduced levels of XPA, ERCC1 and XPF DNA repair proteins in testis tumor cell lines. Int J Cancer 110: 352-361.

Williams SD, Birch R, Einhorn LH, Irwin L, Greco FA, Loehrer PJ (1987) Treatment of disseminated germ-cell tumors with cisplatin, bleomycin, and either vinblastine or etoposide. $N$ Engl J Med 316(23): 1435-1440.

Wood RD, Mitchell M, Lindahl T (2005) Human DNA repair genes, 2005. Mutat Res 577: 275-283.

Yu JJ, Mu C, Lee KB, Okamoto A, Reed EL, Bostick-Bruton F, Mitchell KC, Reed E (1997) A nucleotide polymorphism in ERCC1 in human ovarian cancer cell lines and tumor tissues. Mutat Res 382(1-2): 13-20.

Zhou W, Gurubhagavatula S, Liu G, Park S, Neuberg DS, Wain JC, Lynch TJ, Su L, Christiani DC (2004) Excision repair cross-complementation group 1 polymorphism predicts overall survival in advanced non-small cell lung cancer patients treated with platinum-based chemotherapy. Clin Cancer Res 10: 4939-4943.

(c) (i)(2) This work is licensed under the Creative Commons AY NC SA Attribution-NonCommercial-Share Alike 3.0 Unported License. To view a copy of this license, visit http://creativecommons. org/licenses/by-nc-sa/3.0/ 